\title{
ANALISIS PENGARUH MOTIVASI TERHADAP KEPUASAN KERJA TENAGA PENYULUH KESEHATAN PADA DINAS KESEHATAN KOTA PAREPARE
}

\author{
Analysis of the Effect of Motivation on Work Satisfaction Health Authorization in Health Service \\ City of Parepare
}

\author{
Andi Nasir ${ }^{1}$, Sabrina ${ }^{2}$ \\ ${ }^{1}$ Jurusan Keperawatan Poltekkes Kemenkes Mamuju \\ ${ }^{2}$ Dinas Kesehatan Kota Parepare \\ (andinasir@yahoo.com)
}

\begin{abstract}
ABSTRAK
Penilaian terhadap kepuasan pekerjaan memberikan arti bagi individu, yang memberikan kewenangan untuk membuat keputusandan memecahkan persoalan pekerjaan yang bervariasi dan saling mendukung guna menimbulkan penghargaan atau pengakuan serta memberi umpan balik bagi kinerja. Penelitian ini bertujuan untuk mengetahui pengaruh motivasi kerja intrinsik dan ekstrinsik tenaga penyuluh kesehatan pada Dinas Kesehatan Kota Parepare. Jenis penelitian ini adalah survey analitik dengan rancangan Cross Sectional Study dengan sampelnya 73 orang tenaga penyuluh kesehatan. Data tersebut di olah dengan uji statistik regresi logistic. Hasil penelitian menunjukkan bahwa ada pengaruh prestasi, pengakuan, pengembangan, tunjangan fungsional dan kelengkapan fasilitas operasional terhadap tingkat kepuasan tenaga penyuluh kesehatan Dinas Kesehatan Kota Parepare. Adapun variabel bebas yang paling berpengaruh terhadap kepuasan kerja tenaga penyuluh kesehatan adalah kelengkapan fasilitas operasional. Fakta ilmiah adanya semangat kerja bagi tenaga penyuluh kesehatan bilamana termotivasi oleh faktor pendukung dan penunjang dalam melaksanakan tugas sesuai profesi keahliannya sebagai tenaga fungsional.
\end{abstract}

Kata Kunci : Motivasi, kepuasan kerja, tenaga penyuluh kesehatan

\begin{abstract}
An evaluation of job satisfaction to give meaning to the individual who gave the authority to make decisions and solve problems the work is varied and support each other in order to generate the award or recognition and give feedback to the performance.This research aims to find out the influence of intrinsic work motivation and extrinsic components energy health official at the city Health Office Parepare.The type of this research is to survey analytically with the design of the Cross Sectional Study with members of the sampel have 73 the elimination of energy health. The data in the process with test statistics logistic regression.The results of the study showed that there is the influence of the achievements, recognition, development, functional allowance and completeness of operations against the level of satisfaction of energy health official City Health Office Parepare. Now the free variables that most influence the job satisfaction of energy health official is operational completeness of scientific fact the existence of
\end{abstract}


the spirit of the work for the elimination of power health when motivated by supporting factor and in carrying out the tasks appropriate supporting profession expertise as energy functional.

Keywords : Motivation, job satisfaction, labor health official 


\section{PENDAHULUAN}

Strategi pembangunan kesehatan telah ditetapkan sebagai strategi untuk melaksanakan amanat yang tercantum dalam Sistem Kesehatan Nasional (SKN) 2004 yakni meningkatkan sumber daya manusia dan lingkungan yang saling mendukung dengan pendekatan Paradigma sehat yang memberikan prioritas pada upaya pelayanan kesehatan paripurna (promotif, preventif, kuratif dan rehabilitatif). Ada 4 (empat) pilar strategi pembangunan kesehatan yang saat ini menjadi indikator pencapaian sasaran dalam kaitannya terhadap optimalisasi pelayanan di sektor kesehatan yaitu profesionalisme, pembangunan berwawasan kesehatan, desentralisasi pelayanan kesehatan dan Jaminan pemeliharaan kesehatan masyarakat.

Dalam melaksanakan tugas yang bersifat teknis, bagi tenaga penyuluh kesehatan dalam memberikan promosi kesehatan bagi individu, keluarga, kelompok maupun terhadap masyarakat hendaknya mengutamakan pendekatan melalui jalur komunikasi, keaktifan memberikan informasi dan melakukan edukasi untuk meningkatkan pengetahuan, sikap dan perilaku termasuk penerapan konsep strategi promosi kesehatan (advokasi, bina suasana dan pemberdayaan masyarakat), sehingga berimplikasi pada kepuasaan masyarakat yang dilayani. Sebagai penunjang kebutuhan tenaga penyuluh kesehatan dilingkup Dinas Kesehatan diperlukan kemampuan dalam menganalisa, mengontrol, aktualisasi dan mengevaluasi aspek-aspek keberhasilan pelayanan kesehatan masyarakat yang didukung oleh wawasan pengetahuan keahlian dan profesionalisme ketenagaan. Hal ini terkait dengan kebutuhan seseorang untuk meningkatkan kemampuan dan pengetahuan yang pada akhirnya berimplikasi pada produktivitas kerja. ${ }^{1}$

\section{METODE}

Penelitian ini menggunakan metode survey analitik dengan rancangan Crooss Sectional Study. Populasi dalam penelitian ini adalah seluruh tenaga penyuluh kesehatan yang melaksanakan tugas padaunit kerja Dinas Kesehatan Kota Parepare dan 7 Unit Pelaksana Teknis Dasar (UPTD) Puskesmas yang ada di Kota Parepare. Teknik pengambilan sampel dalam penelitian ini adalah nonprobability sampling dengan cara sampel jenuh (total sampling). Berdasarkan kriteria tersebut didapatkan jumlah sampel sebanyak 73 orang. Instrument yang digunakan dalam penelitian ini adalah kuesioner yang terdiri dari karakteristik responden dan variabel yang akan diteliti (faktor intrinsik : prestasi, pengakuan, sifat pekerjaan, tanggung jawab dan pengembangan dan faktor ekstrinsik : supervisi, tunjangan fungsional dan kelengkapan fasilitas operasional). Data dianalisis dengan menggunakan perangkat computer program SPSS 12.0. Uji statistik 
yang digunakan adalah uji regresi logistik. Analisis data meliputi analisis univariat dan analisis multivariat.

\section{HASIL PENELITIAN}

Karakterisitik responden sesuai Tabel 1 menunjukkan bahwa distribusi responden berdasarkan umur didapatkan yang terbanyak pada kelompok umur $36-45$ tahun yang berjumlah 30 orang $(41,1 \%)$. Jenis kelamin perempuan sebanyak 53 responden $(72,6 \%)$, pangkat golongan responden yang terbanyak yaitu golongan III.a (Penata Muda) sebanyak 27 orang $(37,0 \%)$. Pendidikan responden terbanyak yaitu strata satu (S1) yaitu 47 orang $(64,4 \%)$. Kelompok masa kerja tenaga penyuluh kesehatan yang terbanyak adalah 15 - 23 tahun sebanyak 25 orang $(34,2 \%)$. Jabatan terbanyak sebagai tenaga penyuluh kesehatan ahli yaitu sebanyak 53 orang $(72,6 \%)$.

Distribusi responden sesuai Tabel 2 menunjukkan bahwa prestasi kerja yang baik ada 41 responden $(56,2 \%)$. Variabel pengakuan atas pekerjan baik ada 44 responden $(60,3 \%)$.Ada sebanyak 41 responden $(56,2 \%)$ yang menyatakan sifat pekerjaan baik. Adapun tanggung jawab terbanyak adalah kategori tidak baik sebanyak 42 responden (57,5\%). Variabel pengembangan kategori baik berjumlah 41 responden $(56,2 \%)$.Variabel supervisi dengan kategori baik ada 51 responden $(69,9 \%)$. Variabel tunjangan fungsional dengan kategori baik sebanyak 48 responden $(65,8 \%)$. Kemudian sebanyak 47 responden $(64,4 \%)$ yang menyatakan kelengkapan fasilitas operasional lengkap dengan kategori lengkap. Kepuasan kerja tenaga penyuluh kesehatan ada sebanyak 47 responden $(64,4 \%)$ dengan kategori puas.

Dari uji statistic Pearson Fisher's Exact Test yang telah dilakukan, diperoleh hasil bahwa ada pengaruh prestasi terhadap kepuasan kerja tenaga penyuluh kesehatan $(p=0,014)$, untuk pengakuan juga berpengaruh pada kepuasan kerja tenaga penyuluh kesehatan $(p=0,013)$. Variabel sifat pekerjaan dan tanggung jawab tidak memiliki pengaruh terhadap kepuasan kerja tenaga penyuluh kesehatan $(p=0,258$ dan $p=0,148)$. Variabel pengembangan berpengaruh terhadap kepuasan kerja tenaga penyuluh kesehatan $(p=0,004)$, sedangkan variabel supervisi juga tidak berpengaruh pada kepuasan kerja tenaga penyuluh kesehatan $(p=0,053)$. Adapun variabel tunjangan fungsioanl dan kelengkapan fasilitas operasional masingmasing memiliki pengaruh terhadap kepuasan kerja tenaga penyuluh kesehatan $(p=0,041$ dan $p=0,000)$.

Tabel 4 menunjukkan bahwa setelah melalui analisis regresi logistik berganda ternyata didapatkan variabel yang paling berpengaruh adalah kelengkapan fasilitas operasional yang dapat diartikan bahwa kelengkapan fasilitas operasional besar pengaruhnya terhadap kepuasan kerja tenaga penyuluh kesehatan.Besarnya koefesien determinasi yang berfungsi untuk 
mengetahui besarnya persentase variabel dependen yang dapat diprediksi dengan menggunakan variabel independent. Angka $\mathrm{R}$ square (angka korelasi atau $\mathrm{r}$ yang dikuadratkan) sebesar 0,854. Angka tersebut berarti bahwa sebesar 85,4 \% kepuasan tenaga penyuluh kesehatan dapat dijelaskan menggunakan variabel prestasi, pengakuan, sifat pekerjaan, tanggung jawab, pengembangan, supervisi, tunjangan fungsional dan kelengkapan fasilitas operasional, sedangkan sisanya yaitu 14,6 $\%$ dapat dijelaskan oleh faktor lain. Pada hasil uji Anova hasil pengolahan data SPSS versi 12,0 (lampiran) diperoleh Fhitung sebesar 46,715 dengan tingkat signifikansi 0,000. Karena Fhitung > Ftabel $(46,715>$ 2,77) dan tingkat signifikansi $0,000<0,05$ maka model regresi ini layak untuk digunakan dalam memprediksi kepuasan tenaga penyuluh kesehatan.

\section{PEMBAHASAN}

Hasil penelitian ini menunjukkan bahwa ada pengaruh prestasi terhadap kepuasan kerja tenaga penyuluh kesehatan. Hal ini juga dijelaskan bahwa salah satu kebutuhan manusia yang terkuat adalah kebutuhan untuk merasa berprestasi (sense of achievement) untuk merasa bahwa ia melakukan sesuatu bahwa pekerjaannya tidak penting sering tidak bersemangat di dalam menjalankannya dan sering mengeluh tentang pekerjaannya. ${ }^{2}$ Variabel pengakuan juga berpengaruh pada kepuasan kerja tenaga penyuluh kesehatan. Secara psikologis manusia membutuhkan penghargaan atas setiap kerja yang dilakukannya dalam upaya mempertegas eksistensi keberadaannya, karena dengan adanya pengakuan atau penghargaan akan dapat meningkatkan semangat kerjanya.

Variabel sifat pekerjaan, tanggung jawab dan supervisi tidak memiliki pengaruh terhadap kepuasan kerja tenaga penyuluh kesehatan. Hal ini dijelaskan bahwa Sifat pekerjaan itu sendiri menurut Herzberg merupakan faktor motivasi bagi pegawai untuk berforma tinggi. Pekerjaan atau tugas yang memberikan perasaan telah mencapai sesuatu, tugas itu cukup menarik, tugas yang memberikan tantangan bagi pegawai, merupakan faktor motivasi, karena keberadaannya sangat menentukan motivasi untuk berforma tinggi, ${ }^{3}$ sedangkan setiap orang ingin diikutsertakan dan ingin diakui sebagai orang yang mempunyai potensi dan pengakuan ini akan menimbulkan rasa percaya diri dan siap memikul tanggung jawab yang lebih besar. ${ }^{4}$ Adapun supervisi yang efektif akan membantu peningkatan produktivitas seseorang melalui penyelenggaraan kerja yang baik, pemberian petunjuk-petunjuk yang nyata sesuai standar kerja, dan perlengkapan pembekalan yang memadai serta dukungan-dukungan lainnya

Adapun variabel pengembangan, tunjangan fungsioanl dan kelengkapan fasilitas operasiona juga memiliki pengaruh terhadap kepuasan kerja tenaga penyuluh kesehatan. Tenaga penyuluh kesehatan yang berkualitas mempunyai sikap porfesional dan dapat menunjang 
pembangunan kesehatan, hal tersebut memberi dampak langsung pada mutu penyuluhan pada masyarakat. Terkait dengan tunjangan fungsional hal ini sejalan menurut Robert W. Braid (1999 : 66) tidak ada satu organisasi pun yang dapat memberikan kekuatan baru kepada tenaga kerjanya atau meningkatkan produktivitas, jika tidak memiliki sistem kompensasi yang realistis. $^{5}$

\section{KESIMPULAN}

Pengaruh dari faktor intrinsik dan ekstrinsik memiliki peran penting dalam

\section{DAFTAR PUSTAKA}

1. Notoatmodjo, S. Pengembangan Sumber Daya Manusia. Jakarta: Rineka Cipta; 1998.

2. Ranupandjojo, Heidjrachman dan Husnan Suad. Manajemen Persoalia. Cetakan Kesebelas. Yogyakarta: BPFE; 2004: (188-189).

3. A.Dale Timpe. Motivasi Pegawai. Terjemahan Susanto Budhi Dharma. Jakarta: Gramedia; 1999.

4. Gouzali Saydam. Manajemen Sumber Daya Manusia (Human Resources Management) Suatu Pendekatan Mikro (Dalam Tanya Jawab). Jakarta: Djambatan; 1996: 248.

5. Bacal, Robert. Performance Management. McGraw-Hill Companies, Inc., New York; 1999:66. memberikan pengaruh motivasi terhadap kepuasan kerja tenaga penyuluh kesehatan. Faktor-faktor ini diharapkan memberikan ruang dan kesempatan yang cukup kepada tenaga penyuluh kesehatan yang berprestasi, adanya komunikasi, penghargaan yang baik kepada tenaga penyuluh kesehatan dapat memberikan peluang-peluang kepada tenaga penyuluh kesehatan untuk melakukan pengembangan diri guna meningkatkan pengembangan karir terhadap tenaga penyuluh kesehatan.

6. Adisasmito Wiko. Sistem Kesehatan. PT. Raja Grafindo Persada : Jakarta; 2007.

7. Badan Pendidikan dan Pelatihan. Materi Inti Strategi Promosi Kesehatan. Diklat Fungsional. Makassar; 2010.

8. Badan Penelitian dan Pengembangan Kesehatan Depkes RI, Penyusunan Kuesioner Survei Kesehatan Daerah, Seri 2A. Jakarta; 2003.

9. Bimo Walgito. Psikologi Sosial ( Suatu Pengantar).Yogyakarta : ANDI; 2003.

10. Moleong, J. Lexy. Metodologi Penelitian Kualitatif. Bandung : PT. Remaja Rosdakarya; 1989.

11. Notoadmodjo. Metodologi Penelitian Kesehatan. Cetakan Pertama. Jakarta : Rineka Cipta; 1993. 
12. Singarimbun, $M$ dan Sofian Efendi. Metode Penelitian Survei. Jakarta :Lembaga Penelitian dan Penerangan Ekonomi dan Sosial (LP3ES); 1982.

13. Situs Internet. Pelatihan Tidak Selalu Menyelesaikan Masalah; 2008. [serial online] [diakses pada tanggal 15 April 2017] at http ://id. Wikipedia.org/wiki/Pendidikan dan Pelatihan.

14. Solita sarwono. Sosiologi Kesehatan, Yogyakarta : Gadjah Mada University Press; 1997.

15. ---------. Sistem Kesehatan Nasional : Jakarta; 1998.

16. Sugiyono. Metode Penelitian Administrasi. CV. Alfabeta : Bandung; 2003.
17. Sugiyono. Statistika untuk Penelitian. CV. Alfabeta : Bandung; 2007.

18. ---------. Aplikasi Analisis Multivariate dengan Program SPSS. Semarang :BP. UNDIP; 2001.

19. -----------, Aplikasi Komputer Epi Info \& SPSS, Penuntun Praktikum. STIK Tamalatea : Makassar; 2003.

20. Sulaiman Wahid. Jalan Pintas Menguasai SPSS. Yogyakarta : ANDI; 2000.

21. Suryaputra .N Awangga. Desain Proposal Penelitian. Pyramid Publisher : Yogyakarta; . 2007.

22. Ilmu Kesehatan Masyarakat Prinsip-Prinsip Dasar.Rhineka Cipta : Jakarta; 1997. 


\section{LAMPIRAN}

Tabel 1. Distribusi Frekuensi Karakteristik Responden $(n=73)$

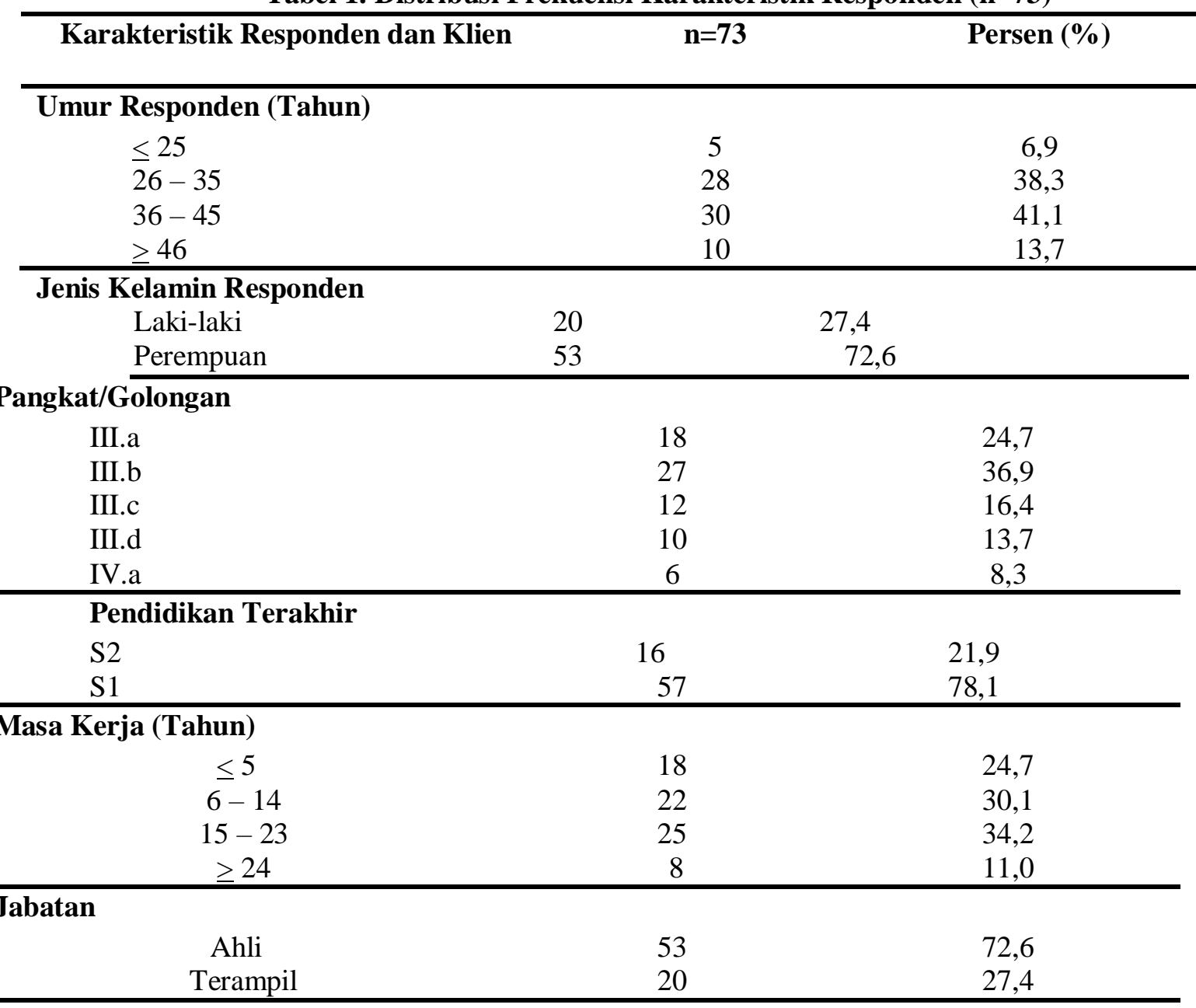

Tabel 2. Distribusi Jawaban Responden berdasarkan Variabel Penelitian Tenaga Penyuluh Kesehatan Pada Dinas Kesehatan Kota Parepare.

\begin{tabular}{|c|c|c|}
\hline Variabel Penelitian & $n=73$ & Persen (\%) \\
\hline \multicolumn{3}{|l|}{ Prestasi } \\
\hline Baik & 41 & 56,2 \\
\hline Tidak Baik & 32 & 43,8 \\
\hline \multicolumn{3}{|l|}{ Pengakuan } \\
\hline Baik & 44 & 60,3 \\
\hline Tidak Baik & 29 & 39,7 \\
\hline \multicolumn{3}{|l|}{ Sifat Pekerjaan } \\
\hline Baik & 41 & 56,2 \\
\hline Tidak Baik & 32 & 43,8 \\
\hline \multicolumn{3}{|l|}{ Tanggung Jawab } \\
\hline Baik & 31 & 42,5 \\
\hline Tidak Baik & 42 & 57,5 \\
\hline \multicolumn{3}{|l|}{ Pengembangan } \\
\hline Baik & 41 & 56,2 \\
\hline
\end{tabular}




\begin{tabular}{lcc} 
Tidak Baik & 32 & 43,8 \\
\hline Supervisi & & \\
Baik & 51 & 69,9 \\
Tidak Baik & 22 & 30,1 \\
\hline Tunjangan Fungsional & & \\
Cukup & 48 & 65,8 \\
Tidak Cukup & 25 & 34,2 \\
\hline Kelengkapan Fasilitas Operasional & & \\
Lengkap & 47 & 64,4 \\
Tidak Lengkap & 26 & 35,6 \\
\hline Kepuasan Kerja Tenaga Penyuluh Kesehatan & & \\
Puas & 47 & 64,4 \\
Tidak Puas & 26 & 35,6 \\
\hline
\end{tabular}

Tabel 3. Pengaruh antara Variabel Penelitian dengan Kepuasan Kerja Tenaga Penyuluh Kesehatan Pada Dinas Kesehatan Kota Parepare.

\begin{tabular}{|c|c|c|c|c|c|c|c|}
\hline \multirow{2}{*}{ Variabel Penelitian } & \multicolumn{4}{|c|}{ Kepuasak Kerja } & \multicolumn{3}{|c|}{ Persen } \\
\hline & Puas & $\%$ & Tidak Puas & $\%$ & & & \\
\hline \multicolumn{8}{|l|}{ Prestasi } \\
\hline Baik & 33 & 80,5 & 8 & 19,5 & 41 & 56,2 & 0,014 \\
\hline Tidak Baik & 14 & 43,8 & 18 & 56,2 & 32 & 43,8 & \\
\hline \multicolumn{8}{|l|}{ Pengakuan } \\
\hline Baik & 34 & 77,3 & 10 & 22,7 & 44 & 60,3 & 0,013 \\
\hline Tidak Baik & 13 & 44,8 & 16 & 55,2 & 29 & 39,7 & \\
\hline \multicolumn{8}{|l|}{ Sifat Pekerjaan } \\
\hline Baik & 32 & 78,0 & 9 & 22,0 & 41 & 56,2 & 0,258 \\
\hline Tidak Baik & 15 & 46,9 & 17 & 53,1 & 32 & 43,8 & \\
\hline \multicolumn{8}{|l|}{ Tanggung Jawab } \\
\hline Baik & 23 & 74,2 & 8 & 25,8 & 31 & 42,5 & 0,148 \\
\hline Tidak Baik & 24 & 57,1 & 18 & 42,9 & 42 & 57,5 & \\
\hline \multicolumn{8}{|l|}{ Pengembangan } \\
\hline Baik & 33 & 80,5 & 8 & 19,5 & 41 & 56,2 & 0,004 \\
\hline Tidak Baik & 14 & 43,7 & 18 & 56,3 & 32 & 43,8 & \\
\hline \multicolumn{8}{|l|}{ Supervisi } \\
\hline Baik & 39 & 76,5 & 12 & 23,5 & 51 & 69,9 & 0,053 \\
\hline Tidak Baik & 8 & 36,4 & 14 & 63,6 & 22 & 30,1 & \\
\hline \multicolumn{8}{|l|}{ Tunjangan Fungsional } \\
\hline Cukup & 39 & 81,2 & 9 & 18,8 & 48 & 65,8 & 0,041 \\
\hline Tidak Cukup & 8 & 32,0 & 17 & 68,0 & 25 & 34,2 & \\
\hline \multicolumn{8}{|l|}{ Kelengkapan } \\
\hline \multicolumn{8}{|l|}{ Fasilitas Operasional } \\
\hline Lengkap & 45 & 95,7 & 2 & 4,3 & 47 & 64,4 & 0,000 \\
\hline Tidak Lengkap & 2 & 7,7 & 24 & 92,3 & 26 & 35,6 & \\
\hline
\end{tabular}


Tabel 4. Hasil Analisis Regresi Logistik antara Pengaruh Motivasi Intrinsik dan Motivasi Ekstrinsik Tenaga Penyuluh Kesehatan PadaDinas Kesehatan Kota Parepare Tahun.

\begin{tabular}{|ll|r|r|r|r|r|r|}
\hline & & \multicolumn{1}{c|}{ B } & \multicolumn{1}{c|}{ S.E. } & Wald & df & \multicolumn{1}{c|}{ Sig. } & Exp(B) \\
\hline Step & PRESTASI(1) & -21.889 & 7636.810 & .000 & 1 & .998 & .000 \\
& PENGAKUAN(1) & -22.875 & 8143.761 & .000 & 1 & .998 & .000 \\
& S.PEKERJAAN(1) & -11.875 & 8969.276 & .000 & 1 & .999 & .000 \\
& T.JAWAB(1) & -22.771 & 8050.371 & .000 & 1 & .998 & .000 \\
& PENGEMBANGAN(1) & -24.016 & 7012.369 & .000 & 1 & .997 & .000 \\
& SUPERVISI(1) & -33.430 & 5890.461 & .000 & 1 & .995 & .000 \\
& TUNJANGAN(1) & -24.477 & 7903.583 & .000 & 1 & .998 & .000 \\
& FASILITAS(1) & -36.608 & 10795.283 & .000 & 1 & .997 & .000 \\
Constant & 98.276 & 14082.067 & .000 & 1 & .994 & $4.8 \mathrm{E}+042$ \\
\hline
\end{tabular}

